\title{
On the Origin of Tourist Behavior
}

\author{
Kock, Florian; Josiassen, Alexander; Assaf, A. George
}

Document Version

Accepted author manuscript

Published in:

Annals of Tourism Research

DOI:

10.1016/j.annals.2018.04.002

Publication date:

2018

License

CC BY-NC-ND

Citation for published version (APA):

Kock, F., Josiassen, A., \& Assaf, A. G. (2018). On the Origin of Tourist Behavior. Annals of Tourism Research, 73, 180-183. https://doi.org/10.1016/j.annals.2018.04.002

Link to publication in CBS Research Portal

\section{General rights}

Copyright and moral rights for the publications made accessible in the public portal are retained by the authors and/or other copyright owners and it is a condition of accessing publications that users recognise and abide by the legal requirements associated with these rights.

Take down policy

If you believe that this document breaches copyright please contact us (research.lib@cbs.dk) providing details, and we will remove access to the work immediately and investigate your claim. 


\section{On the Origin of Tourist Behavior \\ Florian Kock, Alexander Josiassen, and A. George Assaf}

Journal article (Accepted manuscript* )

\section{Please cite this article as:}

Kock, F., Josiassen, A., \& Assaf, A. G. (2018). On the Origin of Tourist Behavior. Annals of Tourism Research, 73, 180-183. https://doi.org/10.1016/j.annals.2018.04.002

00l: 10.1016/j.annals.2018.04.002

* This version of the article has been accepted for publication and undergone full peer review but has not been through the copyediting, typesetting, pagination and proofreading process, which may lead to differences between this version and the publisher's final version AKA Version of Record.

Uploaded to CBS Research Portal: July 2019

(C) 2019. This manuscript version is made available under the CC-BY-NC-ND 4.0 license

http://creativecommons.org/licenses/by-nc-nd/4.0/ 


\title{
ON THE ORIGIN OF TOURIST BEHAVIOR
}

\author{
forthcoming in Annals of Tourism Research
}

Florian Kock ${ }^{1, \text { corresponding author }}$

Assistant Professor

${ }^{1}$ Copenhagen Business School, Department of Marketing, Solbjerg Plads 3, 2000

Frederiksberg, Denmark

fk.marktg@cbs.dk

$+4538152126$

Alexander Josiassen ${ }^{1}$

Professor

aj.marktg@cbs.dk

$+4538152159$

A. George Assaf ${ }^{2}$

Associate Professor

${ }^{2}$ Isenberg School of Management, University of Massachusetts Amherst, Flint Lab 209A, 121

Presidents Drive Amherst, MA 01003, United States of America

$\underline{\text { assaf@isenberg.umass.edu }}$

$+14135451492$ 


\section{On the Origin of Tourist Behavior}

The behavior of modern-day tourists seems embedded in their contemporary lives, with little connection to their ancestral past; the hiking trip to Scandinavia or visiting romantic Paris seem to be fully explainable in a contemporary context. However, this research note makes the case that these decisions are actually rooted in motives that evolved because of the implications they had for our ancestors. Just as Darwin brought a wider lens to the study of species, we motivate that evolutionary psychology provides fertile ground for future tourism research, through a fusion of tourism, psychology and biology. The young research stream of evolutionary psychology has contributed tremendously to understand human behavior in recent years (Griskevicius and Kenrick 2013). The fundamental premise is that modern human beings have inherited psychological mechanisms that predispose them to act in ways that helped our ancestors to survive and procreate. Tourist behavior is a particularly suitable context in which these remnants of the past can be observed, albeit not always in obvious ways. In particular, an evolutionary lens supplements existing tourism research, and provides new and interesting explanations for tourist behavior (Crouch 2013) with resulting implications for theory and practice.

An evolutionary psychology lens distinguishes between proximal (i.e. immediately obvious) and ultimate (i.e. fundamental) motives (Tinbergen 1963). To this day, the overwhelming majority of tourism studies has focused on proximal motives to explain tourist behavior. In the following, and drawing on the fundamental motives framework (Schaller et al. 2017), we introduce five fundamental motives that are of particular interest in a tourist context, and for each explain how an evolutionary psychology lens enhances our understanding of tourist behavior: evading harm, exploration, affiliation, status, and mating. Importantly, evolutionary psychology is not a single research stream but a meta-theory encompassing hundreds of theories. With regard to the limited space, the first motive is discussed in detail in 
order to illustrate the utility of evolutionary psychology; the remaining motives will only be introduced briefly.

Evading harm. Existing studies that examine terrorism often simply conclude that it decreases tourists' travel intention (terrorism is a proximal motive). This observation is correct but provides an incomplete picture at best. We instead suggest an evolutionary approach, thereby asking why people fear terrorism in the first place (i.e. the fundamental reason). Evolutionary psychology suggests that people fear terrorism because of potential harm for the self. The evolutionary motive triggered by terrorism is therefore the evading harm motive that derives from the various dangers that faced our ancestors. The activation of this motive is functional in the way that it predisposes people to engage in various behavior aimed at evading harm. In a similar vein, fear does not exist for its own sake but motivates behavior that diminishes potential harm.

Understanding a behavior not only as a result of a proximal reason, but as a functional (i.e. purposeful) adaptation yields a plethora of novel hypotheses that await testing. The different levels of understanding can be formalized as parts of a process model consisting of a motive-activating cue, a fundamental motive, a proximal motive and a behavior (or behavioral intention). Figure 1 outlines an exemplary process how a cue (e.g., a scary movie, news about terrorism, snake picture, angry face) could drive tourist-behavior according to evolutionary psychology. 
Figure 1: An evolutionary psychology-based process model using an exemplary case

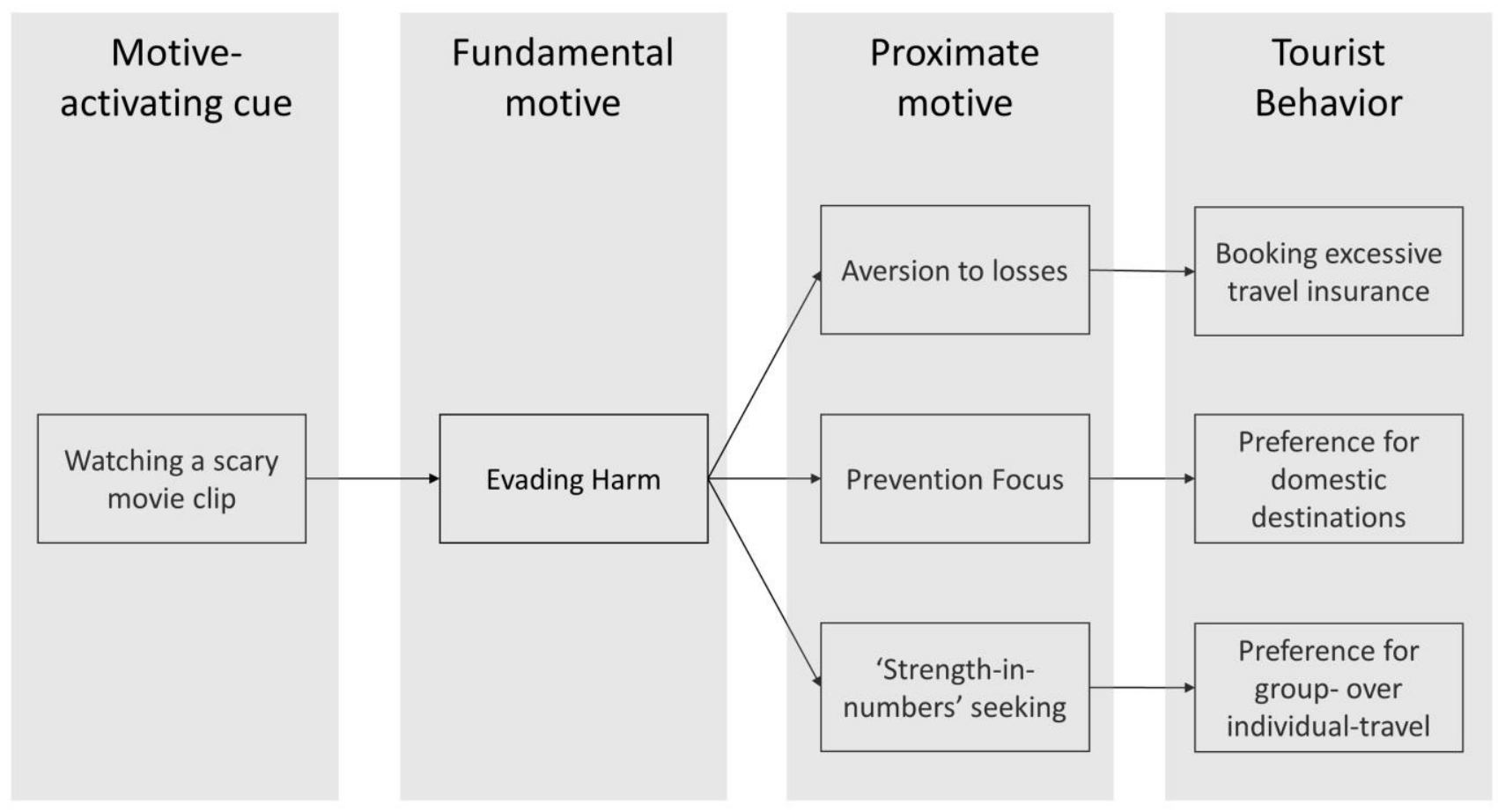

A 'behavioral immune system' that avoids pathogen threats was survival-relevant for our ancestors, and may play an important role in modern-tourist behavior: Due to exposure to cues such as new odors, tastes or sights, travelers are particularly prone to the activation of this system. This evolutionary motive can also prevent interaction with foreigners because foreigners often spread unknown diseases in ancient times. Examining tourist behavior through this motive reveals various exciting research opportunities. For example, researchers could experimentally test how different odors or induced fear cues shape travel behavior.

Exploration. Novelty-seeking has received wide attention in tourism research as one of the key reasons why people travel. Again, we address the deeper-rooted question of why people seek novelty in the first place. Evolutionary biology suggests that our prehistoric ancestors have been living as nomadic hunter-gatherers who had to explore new regions in order to secure resources or find new mating partners. Even in the Neolithic Age, novelty-seeking served as a motivational force that led our ancestors to try new things and seek new experiences, including the intake of new foods and venturing into unknown territories. The exploration system can be 
triggered by unknown or exotic sights, smells or boredom, and predisposes people to become more risk-taking and impulsive.

Affiliation. As the third motive that shapes tourist behavior, we identify affiliation. Humans have always lived in groups in order to increase the probability of survival through resource sharing and by numbers. Today, having friends is important as well, and most people invest heavily in it. Travel and holiday is a particularly suitable vehicle for addressing the motive of affiliation, as it is often experienced in the company of others. Accordingly, many tourism offers capitalize on people's need for affiliation. Specifically, tourists travel to foster relationships (e.g., family trips), to make new acquaintances (e.g., individual backpacking) or to experience a sense of community (e.g., group travels, cruise ships). The affiliation motive is primed by having, making or loosing friends, being part of a group or loneliness, consequently making people more generous, altruistic, extrovert and willing to pay more for products that can be enjoyed together.

Status. While consumers have traditionally used material goods to signal status to other people (conspicuous consumption), travel and holidays have become increasingly important as a status symbol. This trend has been largely fueled by social media which facilitates communication of status-signaling travel activities to others. Status can largely increase survival as alpha leaders had prioritized access to resources, such as food, shelter and mating partners. The status motive can be triggered by competition or rivalry, but also by deprivation of power and low self-esteem. It might result in lower price-sensitivity and increased need to show-off. Understanding travel as a means to signal and obtain status provides intriguing new research angles. For example, and counterintuitively, both the luxury spa customer, the jetsetter and exoticism-seeking backpacker might be driven by the same motive: to signal status to others. 
Mating. The four former survival-relevant motives are meaningless, if individuals did not find someone willing to transport their genes into the next generation. Both in the animal and human world, individuals invest significant resources into reproductive fitness. The mating motive is triggered by attractive potential or actual mating partners, and sexual or romantic cues. While it predisposes men to invest more in luxury goods, credit-based consumption and impulsive buying, women are enticed to invest more in their appearance. In many cases, the holiday serves either as a mate acquisition or mate retention vehicle, such as the romantic trip to Paris with a new partner, the booking of a single ticket to a cruise, the honeymoon trip or sex tourism.

This research note introduces evolutionary tourist psychology to highlight the value of taking an evolutionary lens to understand tourist behavior. An evolutionary lens points to the fundamental reasons for tourist behavior, thereby addressing calls for psychology-based indepth analyses to answer the important question of why people travel (Pearce and Packer 2013). A key insight from evolutionary psychology is that a specific behavior can be elicited when the respective motive is triggered through cues. Accordingly, an important contribution of applying an evolutionary psychology lens is that the same tourist might make different decisions depending on which fundamental motive is currently activated. While the number of motives is limited, they might be activated by various cues, and result in various behaviors, going beyond the proximal motives that often provide only a narrow explanation for a specific behavior. As such, evolutionary psychology highlights parallels between seemingly unrelated behaviors by tracing them back to common fundamental motives of our ancestors.

The focus on fundamental motives, as proposed by evolutionary psychologists, has let some anthropologists and philosophers to question whether the evolutionary root can be empirically validated, or whether behavior can be more directly explained through sociocultural, and thus proximal, motives (Cohen and Bernard 2013). Since this research note 
extends evolutionary psychology to a new research audience, it is important to address this controversy to ensure that tourism research gains the full potential value from taking an evolutionary psychology approach. First, a key strength of evolutionary psychology is that it is based on complementary evidence from various disciplines. For example, the phenomenon of differential parental investment, which underlies the mating motive, exists not only crossculturally but also among most animals, both mammalian and non-mammalian, and is examined by biologists, evolutionary behaviorists as well as social and cognitive psychologists. When not considering an evolutionary lens, neither anthropology nor psychology are able to explain such consistent evidence across cultures and species. Second, theoretical explanations should not be evaluated on their parsimony only but primarily on their comprehensiveness (Kenrick, Saad and Griskevicius 2013). Since evolutionary psychology serves as a meta-theory, and evolutionary psychologists are particularly committed to overcoming lines between disciplines, its explanations would always fare relatively poorly in terms of parsimony in contrast to proximate explanations stemming from one particular theory. However, it is this network of multi-disciplinary consistent evidence that offers unique epistemological and conceptual frameworks for examining existing, and identifying new explanations for human behavior (Saad 2017). For tourism research, an evolutionary approach promotes higher interdisciplinarity and an ethos of methodological pluralism, such as an increasing use of experimental study designs.

A related question raised by philosophers (Cohen and Bernard 2013; Downes 2013) is the one about evidence for the genetic inheritance of the survival systems. Although biologists, particularly those in behavioral ecology, genetics, epigenetics and gene-culture coevolution, present increasing indication for the inheritance of behavioral adaptations, the important question for tourism researchers is another one: Should we wait until philosophers and biologists have, once and for all, solved these issues or should we actively participate in the synthesis of the existence knowledge in the realm of evolutionary psychology in order to 
advance tourism research now? This research note strongly recommends the latter and contends that tourism researchers would benefit from adding an evolutionary perspective to the arsenal of theories available to study matters of tourist behavior. We hope to spur on a research agenda on evolutionary tourist psychology, and suggest that the outlined process model can serve as a starting point for intriguing new insights for academia and practice. Importantly, people everywhere have the same fundamental motives, thus, this lens can be applied cross-culturally. Table 1 concludes with indicative tourism phenomena stimulated by the five motives, highlighting intriguing avenues for evolution-infused tourism research.

Table 1: Fundamental motives and exemplary applications in tourism research 


\begin{tabular}{|c|c|c|c|}
\hline $\begin{array}{c}\text { Fundamental } \\
\text { Motive }\end{array}$ & $\begin{array}{l}\text { Corresponding } \\
\text { Tourism Motive }\end{array}$ & $\begin{array}{l}\text { Exemplary Applications in } \\
\text { Tourism Research }\end{array}$ & Underlying Theories \\
\hline $\begin{array}{c}\text { Evading } \\
\text { harm }\end{array}$ & Security & $\begin{array}{l}\text { Fear of travel, terrorism and } \\
\text { travel safety, travel } \\
\text { insurances, cleanliness, } \\
\text { xenophobia, aviatophobia. }\end{array}$ & $\begin{array}{l}\text { Regulatory focus theory, } \\
\text { endowment effects, error } \\
\text { management theory, Darwinian } \\
\text { gastronomy, intergroup bias } \\
\text { theory, behavioral immune } \\
\text { system. }\end{array}$ \\
\hline Exploration & $\begin{array}{l}\text { Novelty, } \\
\text { Stimulation }\end{array}$ & $\begin{array}{l}\text { Role of curiosity and } \\
\text { boredom, wanderlust, } \\
\text { xenophilia. }\end{array}$ & $\begin{array}{l}\text { Novelty seeking, intergroup } \\
\text { contact theory, openness to } \\
\text { experience. }\end{array}$ \\
\hline Affiliation & $\begin{array}{l}\text { Strengthen } \\
\text { relationships }\end{array}$ & $\begin{array}{l}\text { Traveling in groups, shared } \\
\text { travel experiences, } \\
\text { susceptibility to word-of- } \\
\text { mouth, loneliness, single } \\
\text { travelling. }\end{array}$ & $\begin{array}{l}\text { Attachment theory, social contract } \\
\text { theory, reciprocal altruism. }\end{array}$ \\
\hline Status & $\begin{array}{l}\text { Self- } \\
\text { development, } \\
\text { Recognition }\end{array}$ & $\begin{array}{l}\text { Luxury travel, sharing on } \\
\text { social media, identity } \\
\text { expression, travel during } \\
\text { economic recession, travel } \\
\text { of the financially deprived. }\end{array}$ & $\begin{array}{l}\text { Costly signaling theory, social } \\
\text { dominance orientation theory, } \\
\text { impression management theory. }\end{array}$ \\
\hline Mating & Romance & $\begin{array}{l}\text { Behavioral differences } \\
\text { between genders and age, } \\
\text { romantic travels, sexual } \\
\text { arousal and travel, sex } \\
\text { tourism. }\end{array}$ & $\begin{array}{l}\text { Sexual signaling, costly signaling } \\
\text { theory, inter-sexual selection, } \\
\text { parental investment theory. }\end{array}$ \\
\hline
\end{tabular}

\section{REFERENCES}

Cohen, J. B., \& Bernard, H. R. (2013). Evolutionary psychology and consumer behavior: A constructive critique. Journal of Consumer Psychology, 23(3), 387-399.

Downes, S. M. (2013). Evolutionary psychology is not the only productive evolutionary approach to understanding consumer behavior. Journal of Consumer Psychology, 23(3), 400403.

Crouch, G. I. (2013). Homo sapiens on Vacation: What can we learn from Darwin? Journal of Travel Research, 52(5), 575-590.

Griskevicius, V., \& Kenrick, D. T. (2013). Fundamental motives: How evolutionary needs influence consumer behavior. Journal of Consumer Psychology, 23(3), 372-386. 
Kenrick, D. T., Saad, G., \& Griskevicius, V. (2013). Evolutionary consumer psychology: Ask not what you can do for biology, but.... Journal of Consumer Psychology, 23(3), 404-409.

Pearce, P. L., \& Packer, J. (2013). Minds on the move: New links from psychology to tourism. Annals of Tourism Research, 40, 386-411.

Saad, G. (2017). On the method of evolutionary psychology and its applicability to consumer research. Journal of Marketing Research, 54(3), 464-477.

Schaller, M., Kenrick, D. T., Neel, R., \& Neuberg, S. L. (2017). Evolution and human motivation: A fundamental motives framework. Social and Personality Psychology Compass, 11(6).

Tinbergen, N. (1963). On aims and methods of ethology. Ethology, 20(4), 410-433. 